\title{
TBLA Mastery of Mathematical Concepts Through TPS (Think Pair Share) Learning Model Aided by Conversion Tool Games
}

\author{
Hariyanto ${ }^{1}$, Sri Utaminingsih ${ }^{2}$, Santoso ${ }^{3}$ \\ 123 Program Studi Pendidikan guru sekolah dasar, Universitas Muria Kudus, Kudus, Indonesia.
}

\section{ARTICLEINFO Article history: \\ Received 2 Juni 2020 \\ Received in revised form 12 Juli 2020 \\ Accepted 10 Agustus 2020 \\ Available online 28 Agustus 2020 \\ kata kunci: \\ TPS, matematika \\ permainan alat konversi.}

TPS, mathematical,

conversion tool game. keywords:

\begin{abstract}
A B S T R A K
Tingkat pemahaman konsep matematika yang masih rendah dikarenakan kurangnya penerapan model pembelajaran dan media yang mampu meningkatkan penguasaan konsep kepada siswa. Tujuan penelitian ini adalah mengungkap pola konstruksi penguasaan konsep matematika melalui model pembelajaran TPS berbantuan permainan alat konversi dengan menggunakan Trancript Bassed Learning Analysis (TBLA). Penelitian ini melibatkan siswa kelas 5 berjumlah 28 siswa. Pada penelitian ini terbagi menjadi 2 siklus yaitu siklus 1 berfokus pada materi konversi satuan panjang sedangkan siklus berkonsentrasi pada materi penjumlahan dan pengurangan konversi satuan panjang. Kegiatan dalam setiap siklus akan di rekam melalui video atau audio, kemudian rekaman tersebut akan dijadikan transcript dialog pembelajaran kemudian dianalisis dengan tipe reson komunikasi. Selain analisis transcript pada kegiatan terakhir siswa diberikan ujian tertulis melalui LKS (Lembar Kerja Siswa). Penelitian ini memperoleh hasil bahwa siklus I nilai rata- rata kelas mencapai 75,36, siklus II nilai rata-
\end{abstract} rata mencapai 78,93, dan nilai prosentase kelulusan mencapai $82 \%$. Sehingga dapat disimpulkan bahwa penelitian ini terkait penguasaan konsep penjumlahan dan pengurangan konversi satuan panjang dinyatakan berhasil.

\begin{abstract}
A B S T R A C T
The level of understanding of mathematical concepts is still low due to the lack of application of learning models and media that can improve students' mastery of concepts. The purpose of this study was to reveal the construction pattern of mastery of mathematical concepts through the TPS learning model assisted by conversion tool games using Transcript Based Learning Analysis (TBLA). This study involved 28 students of grade 5. In this study, it was divided into 2 cycles, namely cycle 1 focused on the unit length conversion material while the cycle concentrated on the material addition and subtraction of length unit conversion. Activities in each cycle will be recorded via video or audio, then the recording will be used as a transcript of the learning dialogue then analyzed with the type of communication reson. In addition to transcript analysis in the last activity students are given a written exam through LKS (Student Work Sheet). This study obtained the results that in the first cycle the class average value reached 75.36 , the second cycle the average value reached 78.93 , and the graduation percentage value reached $82 \%$. So, it can be concluded that this research is related to the mastery of the concept of addition and reduction in the conversion of units of length which is successful.
\end{abstract}

\section{Introduction}

Curriculum 2013 has objectives that focus on the cognitive, affective and psychomotor domains. The 2013 curriculum is able to encourage students to develop attitudes, skills and knowledge in a balanced manner, besides that learning with the theme provides benefits for students, namely providing real experiences to students so that learning is more meaningful (Irawan, 2016; Sugiyanto et al., 2015). Through the implementation of the 2013 curriculum students not only receive teacher explanations, but students are required to actively explore their own knowledge from various things and students are required to be able to work together in groups (Fadliyatis et al., 2016; Subadi et al., 2013).

Meaningful learning is able to improve students' initial conceptual development starting from spontaneous concepts that students learn through cultural practices and daily experiences (Haniin et al., 2015; Perdana et al., 2018). Spontaneous means explaining concepts obtained from simple language through the phenomena that occur, so that the students' understanding is so simple that it only gives students a level of knowledge in concrete form and a low level of understanding. To improve higher abstract thinking, students need interaction with teachers who act as mediators in

Copyright (C) Universitas Pendidikan Ganesha. All rights reserved. 
learning who are able to provide meaning and concept development for students (Hendrayana, 2017; Kirna, 2012).

But in reality, one of the learning contents that needs to be improved regarding understanding the concept is mathematics. The content of learning mathematics is a fun subject, but it is still considered a scary subject on any school exam. Learning is less valuable if it is collaborated with a learning model that focuses on teachers (teacher oriented). These facts and conditions are still being carried out in the learning process in elementary schools. This condition directly impacts on the creativity and activity as well as the fighting power of the students in following the lesson, which results in a very low level of understanding and mastery of material concepts. Therefore, it is necessary to have a learning model that needs to be applied to overcome these problems.

The cooperative learning model is very suitable for students because it will be easier to find and understand difficult concepts if they discuss with their friends, students routinely work in groups to help each other solve complex problems (Fardiansyah et al., 2019; Sariayu \& Miaz, 2020). One of the cooperative learning models that is able to improve mastery of the concept of mathematics learning content is the Think Pair Share (TPS) learning model.

Think Pair Share (TPS) learning model is a type of cooperative learning model designed as an effort to influence the student interaction process. After presenting the material, students are expected to think about a task that is stated in more depth and then discuss the answer. This learning model requires students to work together and help each other in small groups of 2-6 students (Sanjaya et al., 2013; Sudirman, 2016; Suryani, 2013).

The Think Pair Share (TPS) type of cooperative learning model is a cooperative learning that is able to create an effective learning activity to vary the atmosphere of discussion patterns in the classroom in order to foster enthusiasm for learning in students. The steps of the Think Pair Share (TPS) learning model include three important stages, namely thinking, pairing, and sharing (Kurniawan et al., 2018; Triwulandari et al., 2017).

Basically, this learning model is student-centered, in which students are more active in seeking information. Students are more independent, not only relying on information from the teacher, but also the teacher has a role as a facilitator. Thus, the learning process in the classroom will be more meaningful. Think Pair Share is also a very good active learning, if implemented correctly, it will save the teacher's time in explaining, help students discuss and participate more, and provide a cumulative assessment of student progress (Fahrullisa et al., 2018; Ladimiyanto, 2014; Yoserizal \& Rahmi, 2019).

The advantage of this TPS learning model is that the structure of this learning model provides equal opportunities for all students to jointly discuss their ideas and share with their friends. This discussion and information sharing activity is very important because students begin to build their knowledge in this discussion. In addition, this activity helps students to find out what they can do about something they don't know yet. This active process is usually not available to students which learning generally. Cooperative learning can increase both individual and classical learning activities and outcomes (Sanjaya et al., 2013; Tembang et al., 2020).

In addition, to support a more effective and fun teaching and learning process, it must be combined with teaching aids that are in accordance with the material in order to help students understand the concepts of the subject matter they are learning. Moreover, the learning objectives in the form of maximum results are more easily realized (Maharani et al., 2017; Nomleni \& Manu, 2018; Sumarni, 2016). In line with this, (Wulandari et al., 2019) stated that teaching aids are learning media that contain or convey the characteristics of the concepts being studied.

The teaching aid used by the researcher is the teaching aid of the conversion concept in the form of a conversion tool game. The advantage of this tool is that students will be more active, not burdened with the material being studied and are game-oriented. Other advantages are: (1) the concept will be easy to understand and embedded in students so that it will always be remembered for a long time, (2) this teaching aid is also easy to make yourself with materials that are found in many school and student home environments, (3) ) besides that, these props are given an attractive color to change the impression of students, if learning mathematics must be serious and focus on being more relaxed, effective and fun (Alawiah et al., 2018; Immawan \& Alimuddin, 2017). In line with (Setyowati et al., 2016), that learning media can stimulate students in learning including duplicating real objects, making abstract concepts into concrete concepts, and providing a learning atmosphere that is not depressed, relaxed and attractive so that it can achieve learning objectives, namely understanding the concept of conversion in mathematics learning.

Creating effective learning requires a Think Pair Share learning model that can be assisted by conversion games, from learning about mastery of mathematical concepts. Then, the researcher 
studied and analyzed it using TBLA analysis (Transcript Based Lesson analysis). The analysis process of TBLA (Transcript Based Lesson Analysis) in this study is to understand the characteristics of learning arrangements in one lesson hour which is divided into several cycles of activity to be analyzed. The knowledge construction pattern describes the development of students in building their own knowledge through class discussions on the length unit conversion material (Haniin et al., 2015; Rohaeti, 2012). In this construction pattern, the emphasis is on mastery of concepts resulting from interactions in the classroom. Therefore, learning practices such as discussions, experiments or performance can influence the construction of students' conceptual mastery.

Several relevant previous studies can be used to determine the novelty of this research with other research, such as: (1) research conducted by experts who obtained the results that the application of the Think Pair Share (TPS) learning model can improve mathematical comprehension skills, (2) research that done by experts (Setyowati et al., 2016) who get the results that by using teaching aids students become easier to understand the material and finally the learning outcomes obtained increase, (3) research conducted by experts (Suhartini, 2015) who obtained the results that the use of TPS learning model assisted by serial images can improve the skills of writing one-act drama scripts for students.

Based on the relevant research, the novelty of this study is to discuss the mastery of the mathematical concept of addition and reduction of unit length conversion through the Think Pair Share (TPS) learning model assisted by the conversion tool game using Trancript Bassed Learning Analysis (TBLA). The purpose of this study is to reveal the construction pattern of mastery of mathematical concepts through the TPS learning model assisted by conversion tool games using Transcript Bassed Learning Analysis (TBLA).

\section{Research Method}

Research design is a method used to collect research data, so that the research results can be proven. Researchers used analytical techniques to analyze data obtained from the research results. This aimed to obtain accurate data in accordance with the research objectives as well as the difficulties faced by students in mastering mathematical concepts with the Think Pair Share learning model and conversion tool games. The subjects in this study involved 28 students of SDN Bendo grade 5 .

The data collection method used in this study was the Transcript Base Lesson Analysis (TBLA) quantitative method. This study focused on the learning transcripts made, learning artifacts and observations of the implementation of learning to see to what extent the influence of the Think Pair Share learning model and unit conversion tool games can improve the ability to master mathematical concepts in unit length conversion learning.

The research would be conducted using 2 learning cycles. Each learning consisted of 3 stages, namely design (preparation), implementation, and reflection. Each cycle would consist of a Think Pair Share learning model assisted by a conversion game tool. Conceptual pattern analysis was carried out at the implementation stage of learning, because this study was made to obtain an overview of the extent to which students mastered the understanding of mathematical concepts in the length unit conversion material.

Data from recording in the form of video and audio on the implementation of learning was used as the main data to analyze the mastery of mathematical concepts with the resonant type of communication that occurs in the mathematics learning process. In addition, researchers used the results of observations and tests as an option to strengthen the analysis carried out.

\section{Result and Discussion}

When the first cycle of learning took place, the researchers collected various learning artifacts either through video or audio and even written for further analysis based on the type of student response to find out the construction of students' knowledge in learning, so that a learning transcript was created.

The transcript that has been formed was then analyzed based on the type of communicative function response, for the analysis of the responses of students in learning mathematics in cycle I can be seen in Figure 1.

\section{ANALISIS RESPON SISWA PEMBELAJARAN MATEMATIKA SIKLUS I}

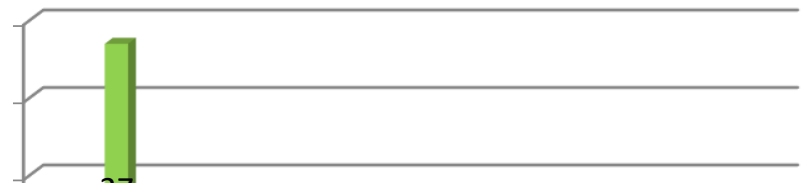


Figure 1. Analysis of Student Responses in Mathematics Learning Cycle I

From the transcript analysis above, it can be seen that the highest student response is code $\mathrm{A}$ (Responsive) where students are enthusiastic about learning so that they are able to answer the questions raised by the teacher. In addition, there is a more dominant response, namely EL (Elaboration) and J (Judgmental) where students begin to develop themselves with the information obtained in learning. From these data it can also be seen that students in providing suggestions, justifying suggestions and summarizing pieces of information are still relatively low so it needs to be facilitated by providing speaking opportunities according to wider learning topics so that students are sharper in critical thinking. This is supported by research from (Pantiwati, 2012) who obtained the results that the Think Pair Share learning model was able to foster students' critical thinking skills.

After analyzing cycle, I was about to analyze the concept of unit length conversion, then the researcher analyzed cycle 2 which contained the concept of addition and subtraction of the length unit conversion. Similar to what was done in cycle 1, namely collecting artifacts in the form of video, audio or chat was collected during learning in cycle 2 . To find out the highest and lowest response codes in learning cycle II, it can be seen in the analysis of the responses of students in learning mathematics cycle II in Figure 2..

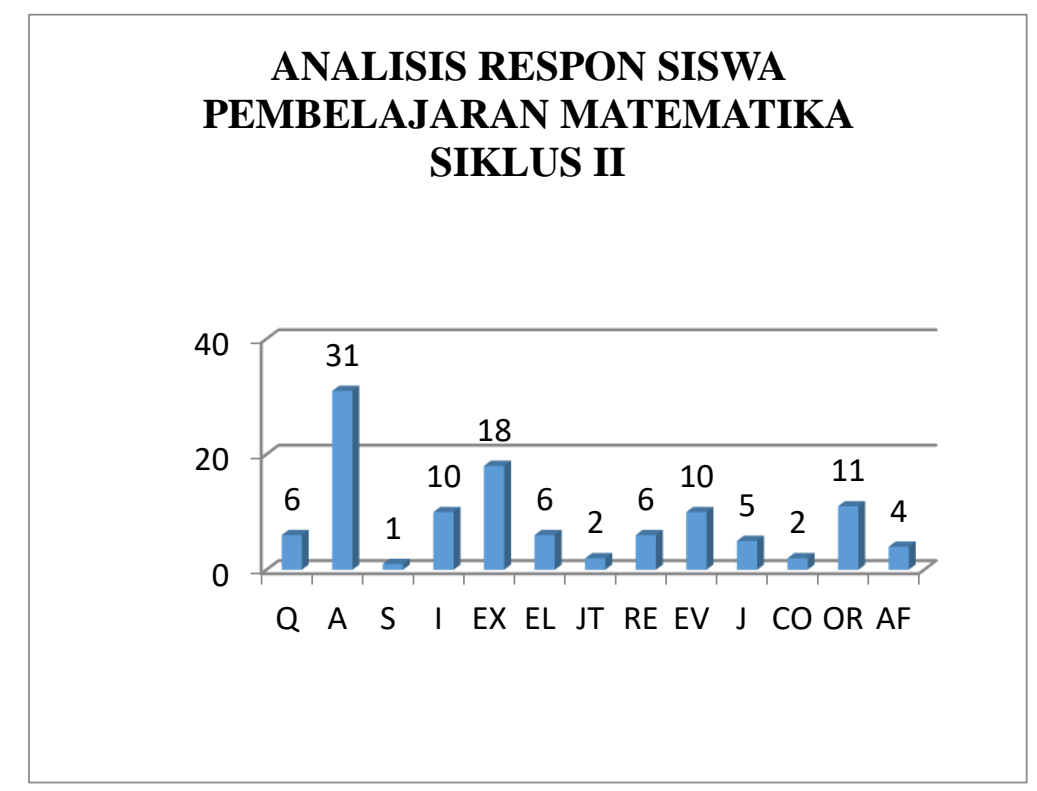

Figure 2. Analysis of Student Responses in Mathematics Learning Cycle II

From the diagram above, the 3 highest responses appear, namely Responsive (A), Exemplification (EX) and Originizing (OR) so it can be concluded that in cycle II learning students are more dominant in answering questions from the teacher, giving examples in real life and can control 
themselves when doing presentations convey the opinion of the group. The diagram above the researcher also focuses on the 3 lowest student responses, namely suggestive (S), Justificational (JT) and Sumarizing (CO), of the three lowest student responses illustrates that learning in the cycle students have not been able to come up with ideas or ideas as suggestions related to the topic learning so that it impacts on confirming or criticizing the opinions of other groups and summarizes some of the information conveyed. This is supported by research from (Fahrullisa et al., 2018) who got the results that the TPS learning model can foster students' mathematical communication skills.

After the second cycle, the students worked on the worksheets to determine the level of completeness or the percentage of completeness. The results of the completeness percentage can be seen in Table 1.

Table 1. Completeness Percentage

\begin{tabular}{lllll}
\hline No & Score & Total Student & Complete & Not Complete \\
\hline 1 & 10 & 0 & 0 & 0 \\
2 & 20 & 1 & 0 & 1 \\
3 & 30 & 0 & 0 & 0 \\
4 & 40 & 3 & 0 & 3 \\
5 & 50 & 0 & 0 & 0 \\
6 & 60 & 1 & 0 & 1 \\
7 & 70 & 5 & 5 & 0 \\
8 & 80 & 5 & 5 & 0 \\
9 & 90 & 4 & 4 & 0 \\
10 & 100 & 9 & 9 & 0 \\
Total & & & 23 & 5 \\
\hline \multicolumn{2}{l}{ Percentage (\%) } & & 82 & 18 \\
\hline
\end{tabular}

From the table above, the passing percentage value reaches $82 \%$, so it can be said that this research is related to the mastery of the concept of addition and reduction of the conversion of length units to be successful. These results are supported by research (Rismayanti et al., 2020) who obtained the results of the study that the application of the Think Pair Share (TPS) learning model can improve the mathematical understanding ability of class VII-8 students of SMP Negeri 18 Bandung.

One of the cooperative learning models that is able to improve mastery of the concept of mathematics learning content is the Think Pair Share (TPS) learning model. The cooperative learning model is very suitable for students because it will be easier to find and understand difficult concepts if they discuss with their friends, students routinely work in groups to help each other solve complex problems. (Fardiansyah et al., 2019; Sariayu \& Miaz, 2020).

Think Pair Share (TPS) learning model is a type of cooperative learning model designed as an effort to influence the student interaction process. After presenting the material, students are expected to think about a task that is stated in more depth and then discuss the answer. This learning model requires students to work together and help each other in small groups of 2-6 students (Sanjaya et al., 2013; Sudirman, 2016; Suryani, 2013).

The Think Pair Share (TPS) type of cooperative learning model is a cooperative learning that is able to create an effective learning activity to vary the atmosphere of discussion patterns in the classroom in order to foster enthusiasm for learning in students. The steps for the Think Pair Share (TPS) learning model include three important stages, namely thinking, pairing, and sharing (Kurniawan et al., 2018; Triwulandari et al., 2017).

Basically, this learning model is student-centered, in which students are more active in seeking information, students are more independent, not only relying on information from the teacher, but the teacher has a role as a facilitator. Thus, the learning process in the classroom will be more meaningful. Think Pair Share is also a very good active learning, if implemented correctly it will save the teacher's time in explaining, help students discuss and participate more and provide a cumulative assessment of student progress (Fahrullisa et al., 2018; Ladimiyanto, 2014; Yoserizal \& Rahmi, 2019). 
The advantage of this TPS learning model is that the structure of this learning model provides equal opportunities for all students to jointly discuss their ideas and share with their friends. This discussion and information sharing activity is very important because students begin to build their knowledge in this discussion, in addition to this activity helping students to find out what they can do that they don't know yet. This active process is usually not available to students in learning in general. Cooperative learning can increase both individual and classical learning activities and outcomes (Sanjaya et al., 2013; Tembang et al., 2020).

In addition, to support a more effective and fun teaching and learning process, it must be combined with teaching aids that are in accordance with the material in order to help students understand the concepts of the subject matter they are learning. So that the learning objectives in the form of maximum results are more easily realized (Maharani et al., 2017; Nomleni \& Manu, 2018; Sumarni, 2016). In line with this, (Wulandari et al., 2019) stated that teaching aids are learning media that contain or convey the characteristics of the concepts being studied.

The teaching aid of the conversion concept used by researchers is in the form of a conversion tool game. The advantage of this tool is that students will be more active, not burdened with the material being studied and are game-oriented. Other advantages are: (1) the concept will be easy to understand and embedded in students so that it will always be remembered for a long time, (2) this teaching aid is also easy to make yourself with materials that are found in many school and student home environments, (3) In addition, this teaching aid is given an attractive color to change the impression of students, if learning mathematics must be serious and focus on being more relaxed, effective and fun (Alawiah et al., 2018; Immawan \& Alimuddin, 2017). In line with this, (Setyowati et al., 2016) that learning media can stimulate students in learning including duplicating real objects, making abstract concepts into concrete concepts, and providing a learning atmosphere that is not depressed, relaxed and attractive so that it can achieve learning objectives, namely understanding the concept of conversion in mathematics learning.Several relevant previous studies can be used to determine the novelty of this research with other research, such as: (1) research conducted by experts who obtained the results that the application of the Think Pair Share (TPS) learning model can improve mathematical comprehension skills, (2) research that done by experts (Setyowati et al., 2016) who get the results that by using teaching aids students become easier to understand the material and finally the learning outcomes obtained increase, (3) research conducted by experts (Suhartini, 2015) who obtained the results that the use of TPS learning model assisted by serial images can improve the skills of writing one-act drama scripts for students.

Based on the relevant research, the novelty of this study is to discuss the mastery of the mathematical concept of addition and subtraction of unit length conversion through the TPS learning model assisted by conversion tool games using Trancript Bassed Learning Analysis (TBLA). The implementation of this research, namely, the Think Pair Share learning model assisted by conversion game tools can be used to create effective and fun learning in the classroom.

\section{Conclusion}

From the research that has been done, namely analyzing the construction of students' knowledge in mastery of mathematical concepts using Transcripts Based Learning Analysis (TBLA), which research is divided into 2 cycles. Cycle I concentrated on mastery of the concept of length unit conversion assisted by the conversion tool playing media, while the second cycle focused on mastering the concept of addition and subtracting the length unit conversion which was assisted by the simple conversion tool game For mastery of mathematical concepts in cycle 1 and cycle 2 with the provision of student worksheets, the worksheets have reached a passing percentage value of $82 \%$, so that the mastery of concepts in both cycles is declared successful and the Think Pair Share learning model is assisted by playing tools conversion can be used to create effective and fun learning in the classroom.

\section{References}

Alawiah, L. T., Rahmatina, D., \& Febrian, F. (2018). Meningkatkan Kemampuan Berpikir Kritis melalui Alat Peraga Pilogma pada Materi Logika Matematika. Jurnal Gantang, 3(1), 55-62. https://doi.org/10.31629/jg.v3i1.384

Fadliyatis, K. S., Harsiati, T., \& Hasanah, M. (2016). Pengembangan Instrumen Asesmen Autentik Keterampilan Menulis Teks Cerpen Dan Teks Fabel Untuk Siswa Smp / Mts. Jurnal Pendidikan, 1(3), 421-427. https://doi.org/http://dx.doi.org/10.17977/jp.v1i3.6168 
Fahrullisa, R., Putra, F. G., \& Supriadi, N. (2018). Pengaruh Model Pembelajaran Kooperatif Tipe Think Pair Share (TPS) berbantuan Pendekatan Investigasi terhadap Kemampuan Komunikasi Matematis. NUMERICAL: Jurnal Matematika Dan Pendidikan Matematika, 2(2), 145-152. https://doi.org/10.25217/numerical.v2i2.213

Fardiansyah, M. A., Purwadi, \& Mudzanatun. (2019). Efektivitas Think Pair Share Terhadap Hasil Belajar Peserta Didik Di SD Pada Materi Analisis Isi Cerita Anak. Sekolah Dasar: Kajian Teori Dan Praktik Pendidikan, 28(2), 66-72. https://doi.org/http://dx.doi.org/10.17977/um009v28i22019p066

Haniin, K., Diantoro, M., \& H, S. K. (2015). Pengaruh Pembelajaran TPS Dengan Scaffolding Konseptual Terhadap Kemampuan Menyelesaikan Masalah Sintesis Fisika. JPS (Jurnal Pendidikan Sains), 3(3), 98-105. https://doi.org/10.17977/jps.v3i3.7875

Hendrayana, A. (2017). Pengaruh pembelajaran pendekatan rigorous mathematical thinking (RMT) terhadap pemahaman konseptual matematis siswa SMP. Jurnal Riset Pendidikan Matematika, 4(2), 186-199. https://doi.org/10.21831/jrpm.v4i2.15385

Immawan, A. Z., \& Alimuddin, H. (2017). Keefektifan Alat Peraga Kartu Kotif Dalam Memudahkan Pemahaman Konsep Operasi Hitung Bilangan Bulatsiswa Kelas VII SMP Negeri 1 Pangkajene. Edumatica, 07(02), 11-21. https://doi.org/10.1017/CB09781107415324.004

Irawan, E. (2016). Implementasi Penanaman Karakter Melalui Matematika Pada Kurikulum 2013. Ibriez: Jurnal Kependidikan Dasar Islam Berbasis Sains, 1(1), 1-18. https://doi.org/10.21154/ibriez.v1i1.4

Kirna, I. (2012). Pemahaman Konseptual Pebelajar Kimia Pemula Dalam Pembelajaran Berbantuan Multimedia Interaktif. Jurnal Ilmu Pendidikan, 18(1), 88-97. https://doi.org/https://doi.org/10.17977/jip.v18i1.3387

Kurniawan, H. R., Elmunsyah, H., \& Muladi. (2018). Perbandingan Penerapan Model Pembelajaran Project Based Learning Dan Think Pair Share Berbantuan Modul Ajar Terhadap Kemandirian Dan Hasil Belajar Siswa Kelas XI di SMKN 3. Jurnal Pendidikan (Teori Dan Praktik), 3(2), 80-85. https://doi.org/10.26740/jp.v3n2.p80-85

Ladimiyanto, A. (2014). Pengaruh Implementasi Pembelajaran Berbasis Masalah dengan Model TAI dan TPS terhadap Hasil Belajar Matematika. Pythagoras: Jurnal Pendidikan Matematika, 9(2), 110-125. https://doi.org/10.21831/pg.v9i2.9073

Maharani, M., Wati, M., \& Hartini, S. (2017). Pengembangan Alat Peraga Pada Materi Usaha dan Energi Untuk Melatihkan Keterampilan Proses Sains Melalui Model Iquiry Discovery Learning (IDL terbimbing). Berkala Ilmiah Pendidikan Fisika, 5(3), 351-367. https://doi.org/10.20527/bipf.v5i3.4043

Nomleni, F. T., \& Manu, T. S. N. (2018). Pengembangan Media Audio Visual dan Alat Peraga dalam Meningkatkan Pemahaman Konsep dan Pemecahan Masalah. Scholaria: Jurnal Pendidikan Dan Kebudayaan, 8(3), 219-230. https://doi.org/10.24246/j.js.2018.v8.i3.p219-230

Pantiwati, Y. (2012). Pengaruh Asesmen Biologi Dalam Pembelajaran Think Pair Share Terhadap Kemampuan Kognitif Siswa. Jurnal Ilmu Pendidikan, 18(2), 236-243. https://doi.org/http://dx.doi.org/10.17977/jip.v18i2.3626

Perdana, G. P., Suma, K., \& Pujani, N. M. (2018). Pengaruh Struktur Teks Terhadap Penguasaan Konsep Dan Penurunan Miskonsepsi Pada Listrik Dinamis. Jurnal Pendidikan (Teori Dan Praktik), 3(1), 13-18. https://doi.org/http://dx.doi.org/10.26740/jp.v3n1.p13-18

Rismayanti, E., Kartasasmita, B. G., \& Supianti, I. I. (2020). Peningkatan Kemampuan Pemahaman Matematis Siswa Melalui Model Pembelajaran Think Pair Share. JNPM (Jurnal Nasional Pendidikan Matematika), 4(1), 154-167. https://doi.org/10.33603/jnpm.v4i1.2930

Rohaeti, E. E. (2012). Analisis Pembelajaran Konsep Esensial Matematika Sekolah Menengah Melalui Pendekatan Kontekstual Socrates. Infinity Journal, 1(2), 186-191. https://doi.org/10.22460/infinity.v1i2.18

Sanjaya, B., Wati, M., \& An'nur, S. (2013). Meningkatkan Hasil Belajar Siswa Melalui Penerapan Pembelajaran Kooperatif Tipe Think Pair-Share(TPS). Berkala Ilmiah Pendidikan Fisika, 1(3), 278-289. https://doi.org/10.20527/bipf.v1i3.887 
Sariayu, M. R., \& Miaz, Y. (2020). Peningkatan Aktivitas Belajar Siswa Melalui Model Think Pair Share di Sekolah Dasar. Jurnal Basicedu, 4(2), 295-305. https://doi.org/10.31004/basicedu.v4i2.337

Setyowati, N., Susilo, B. E., \& Masrukan, M. (2016). Penggunaan Alat Peraga untuk Meningkatkan Hasil Belajar dan Keaktifan Siswa Mata Diklat Matematika Materi Peluang. Kreano, Jurnal Matematika Kreatif-Inovatif, 7(1), 24-30. https://doi.org/10.15294/kreano.v7i1.4831

Subadi, T., Priyono, K. D., Dahroni, \& Musyiyam, M. (2013). Implementasi Pembelajaran IPS Berbasis Kurikulum 2013 Melalui Lesson Study Di Sekolah Muhammadiyah Kartasura. WARTA, 18(1), 62-76. https://doi.org/https://doi.org/10.23917/warta.v18i1.1168

Sudirman, S. (2016). Penerapan Model Pembelajaran Think Pair Share Untuk Meningkatkan Hasil Belajar IPA Siswa. Jurnal Pendidikan Fisika, 4(1), 59-67. https://doi.org/10.24127/jpf.v4i1.394

Sugiyanto, S., Kartowagiran, B., \& Jailani, J. (2015). Pengembangan Model Evaluasi Proses Pembelajaran Matematika Di SMP Berdasarkan Kurikulum 2013. Jurnal Penelitian Dan Evaluasi Pendidikan, 19(1), 82-95. https://doi.org/10.21831/pep.v19i1.4558

Suhartini, S. (2015). Peningkatan Keterampilan Menulis Naskah Drama Satu Babak Menggunakan Model Think-Pair-Share Berbantuan Alat Peraga Gambar Berseri. Satya Widya, 31(2), 83-89. https://doi.org/10.24246/j.sw.2015.v31.i2.p83-89

Sumarni, S. (2016). Upaya Meningkatkan Kemampuan Berhitung Melalui Penerapan Model Pembelajaran Numbered Heads Together Dengan Pemanfaatan Alat Peraga Sederhana Materi Pembagian Siswa Kelas Ii. Refleksi Edukatika: Jurnal Ilmiah Kependidikan, 7(1), 61-68. https://doi.org/10.24176/re.v7i1.1813

Suryani, E. (2013). Meningkatkan Hasil Belajar Ekonomi Melalui Pembelajaran Kooperatif Metode Think Pair Share pada Siswa Kelas XI SMA Negeri 3 Mataram. Jurnal Kependidikan, 4(2), 141150. https://doi.org/10.1017/CB09781107415324.004

Tembang, Y., Purwanty, R., \& Hermansyah, A. K. (2020). Implementasi model think pair share berbantuan media Kahoot It meningkatkan keaktifan berdisikusi mahasiswa. Premiere Educandum: Jurnal Pendidikan Dasar Dan Pembelajaran, 10(1), 22-33. https://doi.org/10.25273/pe.v10i1.5368

Triwulandari, D., Wati, M., \& Miriam, S. (2017). Perbedaan Hasil Belajar Siswa Antara Menggunakan Model Pembelajaran Kooperatif Tipe Think Pair Share Dengan Tipe Pair Checks. Berkala Ilmiah Pendidikan Fisika, 5(1), 99-108. https://doi.org/http://dx.doi.org/10.20527/bipf.v5i1.2816

Wulandari, R., Swistoro, E., \& Firdaus, M. L. (2019). Penerapan model pembelajaran problem solving fisika berbantuan alat peraga kolektor surya pada pembelajaran kalor di SMA IT Iqra. Pendipa Journal of Science Education, 3(3), 154-159. https://doi.org/10.33369/pendipa.v3i2.7612

Yoserizal, \& Rahmi, U. (2019). Perbedaan Aktivitas Belajar Siswa Antara Model Cooperative Learning Tipe Snowball Throwing Dengan Tipe Think Pair Share. Jurnal Basicedu, 3(2), 1055-1064. https://doi.org/https://doi.org/10.31004/basicedu.v3i4.247 